\title{
LEGAL TRANSLATION COMPETENCE IN THE LIGHT OF TRANSLATIONAL HERMENEUTICS
}

\begin{abstract}
This paper is concerned with the concept of translation competence as seen from the perspective of translational hermeneutics. The first part of the article provides a short survey of how translation competence and its development has been described so far, with a particular focus on the legal translator's skills and abilities. The second part of the paper briefly presents the notion of translational hermeneutics together with its main concepts. The aim of this part of the article is also to show similarities between the translation phenomenon and hermeneutical studies. Finally, building on Stolze's (2011) hermeneutical model of translation, the last part of the paper presents the main features of a hermeneutical model of legal translation competence.
\end{abstract}

Keywords: translation competence, legal translation competence, translational hermeneutics, legal translation

\section{Translation competence - state of the art}

Translation competence has gained increased interest in Translation Studies since the 1990s. It has to be realized, though, that the first attempts at defining the concept were made in the late 1970s (Wills, 1976; Harris, 1977; Harris \& Sherwood, 1978; Koller, 1979), and they were very much in line with Applied Linguistics and its language acquisition theory, especially with reference to linguistic competencies and bilingualism. Competence was regarded then as a summation of linguistic competencies. However, the ideas, as Pym explains (2003:483), were short-lived. With some historical changes, namely the separation of Applied Linguistics and Translation Studies, other definitions and multicomponential models of translation competence appeared. It has to be noted that the concept, despite many attempts at determining what it really comprises, is quite vague and abstract. Orozco and Hurtado Albir (2002:376) rightly stress that there are several authors and researchers who mention translation competence in their works and who, probably, have a concrete definition of it in mind, but 


\section{Beata Piecychna}

they do not make it explicit. It can be said that in the Translation Studies literature there are only a few explicit and clear definitions of translation competence.

One of the first definitions of translation competence is given by Bell (1991:40-41) who proposes both a translator expert system consisting of various types of knowledge and procedures necessary for translational process (source language knowledge, target language knowledge, text-type knowledge, domain knowledge, and contrastive knowledge, as well as an inference mechanism that permits the decoding of texts and the encoding of texts) and a model of communicative competence consisting of four sub-competencies: grammatical, sociolinguistic, discourse, and strategic. Bell (1991:43) defines translation competence as "the knowledge and skills the translator must possess in order to carry it [the translation] out". A similar approach is presented by Hurtado Albir (1996:48) who states that translation competence is "the ability of knowing how to translate", and by PACTE research group (2011:318) who propose the following definition: "the underlying system of knowledge and skills needed to be able to translate". Furthermore, the research group states (2003:55) that in general, translation competence is a construct that is not subject to direct observation, that it is expert knowledge and that it should be defined, taking into consideration both declarative and procedural knowledge (2003:58). The definition of translation competence as "the system of underlying kinds of knowledge, whether declarative or operative, which are needed for translation" is also given by Presas (2000:28) who additionally specifies what types of knowledge are necessary in the process of translation, namely knowledge of both source and target language, knowledge of the real world and use of the material, the ability to use translator's tools (dictionaries, terminological bases, etc.), cognitive abilities such as creativity, or the ability of problem-solving.

From the point of view of translation didactics, translation competence is defined as a construct consisting of knowledge, skills, attitudes, and aptitudes necessary for translation task realization (Kelly, 2005:162). A very interesting suggestion is made by Pym (2003:489) who, in defence of minimalism, redefines the concept of translation competence and regards it as the ability to generate viable target texts and the ability to select only one of those versions with "justified confidence". As Pym emphasizes, the real value of this type of definition lies in the large number of things that it does not even mention (490). This minimalist definition brings to mind the concept of "supercompetence" (Wilss, 1982:58) reflecting the "singular specificity of translation" (Pym, 2003:488). 
In the light of this article, it is worth mentioning Bukowski (2012:131136) who describes a translator's hermeneutical competences: responsibility for one's own interpretation of the message being translated, knowledge of cultural and historical context, knowledge of literature of a given nation, detailed and general erudition, and the ability to converse with a given text.

As has been mentioned, some authors approach the concept of translation competence from a multicomponential perspective. For instance, Neubert (2000:5), apart from describing components of translational competence, which he names parameters, also presents contextual features of translation competence, namely complexity, heterogeneity, approximation, open-endedness, creativity, situationality, and historicity, stating that they are bound up with each other. According to the author (2000:7-10), the parameters of translation competence are as follows: language competence, textual competence, subject competence, cultural competence, and transfer competence.

Other authors who use the component approach to translation competence are, just to name a few, Hurtado (1996) who distinguishes linguistic, extralinguistic, textual, general professional skills, and transfer competences; Shreve (2006) who stresses that translation competence consists of linguistic knowledge, cultural knowledge, textual knowledge, and translation knowledge; or Kelly (2005:33-34) who describes the following competences: communicative and textual, cultural and intercultural, subject area, professional and instrumental, attitudinal (psychophysiological), strategic, and interpersonal. Among Polish scholars, it is mainly Hejwowski (2004:154) who deals with translation competence. He describes the following elements of the concept: source and target language knowledge, the skill of matching various structures on the basis of their relative similarity, knowledge of source and target language cultures, general and specialized knowledge, communicative skills, perseverance in seeking to maintain message sense, knowledge about translation theory, and personality features and predisposition. It is also interesting to note that some authors (see: Kiraly 1995:16-17) suggest that a translator competence approach is preferable to translation competence. In this sense translator competence means more general communicative skills in both source and target languages, which can be seen both in bilinguals and in translators.

Recently, the most famous models of translational competence have been those of the PACTE, TransComp, and EMT research groups. Let us briefly analyze them. According to the PACTE research group (2003:58$59)$, translation competence can be divided into five sub-competencies. They are as follows: bilingual sub-competence which is mainly procedural knowl- 


\section{Beata Piecychna}

edge, extra-linguistic sub-competence which is mainly declarative knowledge (both implicit and explicit), knowledge about translation sub-competence which is mainly declarative knowledge (both implicit and explicit), instrumental sub-competence which is mainly procedural knowledge, strategic sub-competence which is predominantly procedural knowledge, and psychophysiological components which can be described as "different types of cognitive and attitudinal components and psycho-motor mechanisms (memory, perception, attention, emotion, intellectual curiosity, perseverance, rigour, critical spirit, knowledge of and confidence in one's own skills and abilities, motivation, creativity, logical reasoning, etc.). Apart from this holistic model of translation competence, the PACTE research group has developed a dynamic model of translation competence acquisition which is defined as "a dynamic, spiral process that, like all learning processes, evolves from novice knowledge (pre-translation competence) to expert knowledge (translation competence); it requires learning competence (learning strategies) and during the process both declarative and procedural types of knowledge are integrated, developed and restructured" (2003:49).

As mentioned, the other famous model of translation competence was developed by Göpferich (2007) within the framework of a longitudinal study called TransComp. Göpferich (2009:21-23) differentiates between the following sub-competences: communicative competence in at least two languages, domain competence, tools and research competence, translation routine activation competence, psychomotor competence, and strategic competence. It has to be added that the TransComp project is aimed at analyzing translation competence development in its continuity (26) and at the measurement of the following components of the competence: 1) strategic competence, 2) translation routine activation competence, and 3) tools and research competence. The reason for the selection of sub-competences lies in the assumption that the afore-mentioned competences are "the main translation-specific competences in which translation competence differs from the competence of bilingual persons with no specific training in translation" (30).

The EMT translation competence framework consists of six competences: translation service provision, language, intercultural, info mining, technological, and thematic. Competence as such is defined by EMT experts as "combination of aptitudes, knowledge, behaviour and know-how necessary to carry out a given task under given conditions" (2009:3-4).

To the best of my knowledge, apart from the PACTE and TransComp empirical models of translation competence development, Campbell's model (1991), and Alves' and Gonçalves work (2007), generally speaking, there 
is a lack of empirical research on translation competence and its acquisition. Despite the fact that there have been few empirical studies concerned with the comparison of performance of translation students and professional translators (see: Krings, 1988; Jääskeläinen, 1989; TirkkonenCondit, 1990; Lorenzo, 1999) and with translation competence components (see: Kussmaul, 1991; Fraser, 1993; Schäeffner, 1993; Dancette, 1994, 1995; Alves, 1996; Livbjerg \& Mees, 1999), most of these studies present major problems both from the scientific and the theoretical point of view (Orozco \& Hurtado Albir, 2002:377-378). Furthermore, as Whyatt rightly concludes (2012:167), nobody has yet researched the process of translation competence development in translation students. To the best of my knowledge, there are also only a few works which examine the concept of translation competence with reference to legal translation. Let us now briefly analyze them.

\section{What does it take to translate legal texts?}

It is generally agreed that a professional legal translator should be an expert both in linguistics and, at least to some extent, law. What is more, as Šarčevič states (1997:113-114), legal competence comprises not only thorough knowledge concerned with legal terminology but also in-depth understanding of logical principles, logical reasoning, the ability of problemsolving, the ability of text analysis, and knowledge of the target and source legal system. In her article entitled Translation and the Law: An interdisciplinary approach Šarčevič (1994:304) stresses also the importance of knowledge of drafting techniques for different text types and the need of training in legal hermeneutics:

In particular, the structure of the text and its constituent legal sentences is of vital importance. For example, translators must be able to identify and produce all forms of obligations, prohibitions, statements of permission and authorization in the target legal system. Moreover, translators need training in legal hermeneutics. Although they do not interpret texts as judges do, they must be able to foresee how the text will be interpreted by the competent court. (Šarčevič, 1994:304)

The need for legal hermeneutics training should be of no surprise, because, as Gadamer (2004) repeatedly stresses, every translator is an interpreter. Therefore, I also propose to take a similar stance, and agree fully with Šarčevič, especially when taking into consideration the fact that contem- 


\section{Beata Piecychna}

porary legal translation teachers, generally speaking, neglect the aspect of interpretation skills in the translation training process.

There are, however, many more skills that a competent legal translator ought to possess. Let us refer to Sofer $(2006: 107)$ who states that in order to translate legal texts properly and efficiently, a legal translator must possess good writing skills. It goes without saying that a legal translator without a good command of his own written native language lacks an important aspect of translation competence, namely communicative competence. A legal translator, according to Obenaus (1995:250), should also possess good information brokering skills, which simply means that such a person should be able to find the right information quickly and effectively.

In addition, Sofer (2006:106) emphasizes that a legal translators' task is to pay special attention to legal documents, develop good legal reference resources and awareness of legal systems, both target and source, and different specialties within legal fields, as well as raise consciousness as to the importance of the legal documents which comprise their translations. At the same time, we should not underestimate the role of translation theory in the concept of translation competence, including legal translation. Šarčevič (1997:271) rightly says that in this case [legal translation], a special theory of legal translation is necessary, theory which takes into consideration legal criteria. According to the author, the theory, in order to be effective, must be practice-oriented. It is also interesting to note that in her study, Šarčevič (1997) defines legal translation as "an act of communication in the mechanism of law".

It is not only Šarčevič who discusses legal translation in terms of expertise both in language and law, since almost every author writing about this type of translation emphasizes that a legal translator must be, at least to some extent, an expert not only in translation studies but also in law. However, to the best of my knowledge, nobody specifies the extent of expertise in the law field. It is worth noting what Cao (2007:5) says in this respect:

The legal translator's skills and tasks are very different from the lawyer's. The legal translator does not read and interpret the law the way a lawyer does. The legal translator does not write the law either. However, the legal translator needs to know how lawyers, including judges and lawmakers, think and write and how they write the way they do, and at the same time, to be sensitive to the intricacy, diversity and creativity of language, as well as its limits and power. (Cao, 2007:5)

It can be argued, though, that it would be enough for legal translators just to know how lawyers think or write law, and to be sensitive to some language 
intricacies. Besides, Cao's claim concerning the legal translator's knowledge regarding the way lawyers think poses another problem of an interpretive nature. How can anyone learn or get to know how someone else thinks? It is worth considering if this is indeed ever possible. It seems, then, that we should first and foremost find a different answer to the question concerning legal translators competences. Besides, I believe that more helpful for legal translators would be to know how a lawyer interprets the law (therefore, knowledge of legal hermeneutics is critically important, as Šarčevič emphasizes) than just to know how a lawyer thinks about the law.

Gouadec's view seems very relevant in this respect. He (2007:31) claims that in situations when a legal translator is not himself a lawyer or does not have a solid legal background, it "should always be a joint effort by a translator and a lawyer, the latter having the last say, of course". Wills (1996:73) approaches the question in a similar fashion, stating that, without doubt, translators who are experts in the legal domain do their job better than literary translators, who do not possess the relevant domain-specific knowledge. Similarly, Prieto Ramos (2011:13) underlines the necessity of understanding and producing legal translations with "lawyer-linguist" eyes, which simply means that a legal translator should be familiar with legal reasoning, interpretation rules, legal phraseology, legal sources used by jurists, and legal structures and procedures with reference to particular types of legal systems. It seems, then, that an ideal legal translator should be a lawyerlinguist, a professional able to connect legal and specialized linguistic skills, and, consequently, a person who should possess very good knowledge and skills within the scope of both law and linguistics and, consequently, legal text interpretation abilities. However, again, the question of the scope of expertise in law remains open. If we agree that legal translators should be experts in law and be familiar with at least one field of the domain, be it civil law, criminal law, family law, etc., we should first try to determine the extent of the knowledge that is necessary of both source and target legal systems. This issue, however, is beyond the scope of this paper. In order to evaluate the specificity of legal translation competence within the frame of knowledge of the law and its fields, further research based on professional legal translators' work is needed.

Due to the fact that legal translation is regarded as one type of specialized translation, the majority of authors writing about legal translation competence rightly emphasize that legal translation requires familiarity with legal terminology. As Trosborg (1997:156) emphasizes, the translation competence of a legal translator must comprise the distinctive lexical features of legal vocabulary. The necessity of the knowledge of legal terminology should 


\section{Beata Piecychna}

be of no surprise, since all legal translators are faced with comparative law during the translational process, and their core activity is the comparison of legal terminology of source and target text systems.

In the light of the possibilities for further research in the field of translation being discussed, also very important is the determination of specific components of legal translation competence, because, to the best of my knowledge, there is only one known model of legal translation competence, which has been developed by Prieto Ramos (2011). Of course, many authors mention legal competence in their writing (see: Cao, 2007), and even try to define it, but they do not propose models that would be helpful in understanding the concept of a legal translator's competence from a holistic perspective. Prieto Ramos' holistic model is based on previous paradigms, especially that of the PACTE research group, and aims at simplifying reference to those skills which are possessed by a professional. According to Prieto Ramos (2011:12), there are five sub-competences comprising declarative and operative knowledge, and they are presented in the Table 1 below.

\section{Table 1}

\section{Sub-competences of legal translation competence and their description}

(based on Prieto Ramos 2011)

\begin{tabular}{|l|l|}
\hline $\begin{array}{l}\text { Name of sub-competence of } \\
\text { legal translation competence }\end{array}$ & \multicolumn{1}{|c|}{ Description of the sub-competence } \\
\hline $\begin{array}{l}\text { Strategic or methodological } \\
\text { sub-competence }\end{array}$ & $\begin{array}{l}\text { Controls the application of the other skills; comprises the } \\
\text { analysis of translation brief, macrocontextualization and } \\
\text { work planning, problem identification, transfer strategies } \\
\text { use, self-assessment, quality control }\end{array}$ \\
\hline $\begin{array}{l}\text { Communicative and textual } \\
\text { sub-competence }\end{array}$ & Linguistic, sociolinguistic, and pragmatic knowledge \\
\hline $\begin{array}{l}\text { Thematic and cultural } \\
\text { sub-competence }\end{array}$ & $\begin{array}{l}\text { Legal systems knowledge, branches of law knowledge, } \\
\text { awareness of main legal concepts and differences between } \\
\text { different legal cultures and systems }\end{array}$ \\
\hline Instrumental sub-competence & $\begin{array}{l}\text { Specialized sources knowledge, terminology management, } \\
\text { parallel texts use, computer tools knowledge }\end{array}$ \\
\hline $\begin{array}{l}\text { Interpersonal and professional } \\
\text { management competence }\end{array}$ & Teamwork, cooperation with clients and colleagues \\
\hline
\end{tabular}

Apart from these five sub-competences, Prieto Ramos (2011:13) mentions other elements of legal science and legal linguistic knowledge, which contribute to legal translation competence. They are as follows: the scope of 
specialization (the classification of legal genres), comparative legal linguistics (the features of legal discourse in the source and target languages), documentation (specialized legal sources), and professional practice (the knowledge of legal translation market conditions, deontology issues in legal translation). However, to the best of my knowledge, apart from the above model nobody has developed a system of legal translation competence and its acquisition. It is obvious that we need more suggestions and propositions concerning the shape of translation competence with reference to legal professionals dealing with translation or translators being specialized in law. Therefore, in this article, an attempt is made to present a legal translation competence model as seen from the translational hermeneutics perspective. It is hoped that the proposed model will be helpful in the development of a theoretical construct of the professional legal translator and will suggest a practical way of using this theoretical knowledge in legal translation teaching. Firstly, however, let us briefly describe the main concepts of translational hermeneutics.

\section{Translational hermeneutics}

Translational hermeneutics is a relatively unknown sub-discipline of translation studies. Its main proponents are German scholars, namely Radegundis Stolze from the Technische Universität of Darmstadt, John W. Stanley from Fachhochschule Köln, and Larisa Cercel from AlbertLudwigs-Universität Freiburg. The aim of the research group is to develop and exchange ideas concerning the hermeneutical approach to translation studies.

The connection of translation studies and hermeneutics should be of no surprise. Hermeneutics, similarly to translation studies, is concerned mainly with interpretation, explanations, language, understanding, meaning, and finally, translation. As Palmer (1969:33) says, contemporary hermeneutics finds within translation and translation theory a special "reservoir" for exploring hermeneutical issues, and the phenomenon of translation is, in some ways, a key matter for hermeneutical studies. According to Hermans (2009:130), viewing the phenomenon of translation as a discipline closely related to hermeneutics points to "contiguity of intra- and interlingual translating as the negotiation of difference and otherness". Furthermore, translation, considered as interpretive practice, is framed by hermeneutic concepts (Hermans, 2009:130). According to Stolze (2011:141), hermeneutical philosophy is concerned mainly with the individual as a so- 


\section{Beata Piecychna}

cial and historic person who seeks to orient himself in the world that surrounds him, understand the world and other people, and act together with others in a given society. All these considerations are relevant for translation studies.

The paradigm of translational hermeneutics focuses on the concept of "the translator as a competent person" (Stolze, 2011:45) and on six main aspects of this concept: subjectivity, historicity, process character, holistic nature, phenomenology, and reflection (for detailed analysis of the aspects see Stolze 2013:57-58). The paradigm "reflects on the conditions of comprehension as a human outlook towards the world" (Stolze, 2011:45).

The author of the present paper believes that translational hermeneutics, as a research paradigm in translation studies, can offer new insights into translation theory, especially with reference to the creation of new translational competence models, since, as can be seen from the first and second parts of the article, the majority of authors, for unknown reasons, neglect the importance of understanding and text interpretation as necessary skills in the work of any translator. After all, the core of translational activity, the fundamental elements on which all the above concepts rest, is understanding and interpretation. Without them no translation is possible. Therefore, the model of hermeneutical translation competence of legal translators, as proposed in this paper, is based on the concepts of understanding and interpretation as pivotal elements of all the sub-competences described below. Firstly, however, let us look briefly at what constitutes the hermeneutical act of translation.

\section{Radegundis Stolze's hermeneutical model of the act of translation}

As Stolze (2011:177) states, in a hermeneutical model of translation, it is the translator who is the central element in the translational process. Therefore, in the hermeneutical model of legal translator competence, we will focus mainly on the translator and his activities during translation. Translation competence seen from a hermeneutical point of view may be described as a dynamic concept in which procedural knowledge is of paramount importance, integrating as many issues and aspects as possible and ensuring the highest versatility for professional translation activities (Stolze, 2011:179-180). Let us now look closely at a hermeneutical process of translation, namely its two stages: translational reading and translational writing. 
Figure 1

Model of a hermeneutical translational reading stage

(based on Stolze, 2011:105-127)

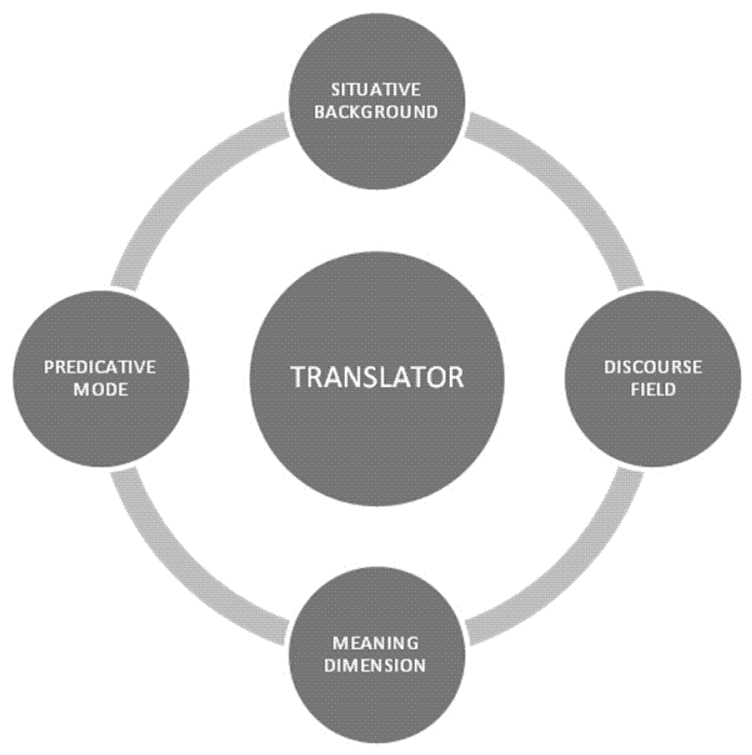

As can be seen from the figure above, the first stage of the translation process, called translational reading, consists of four elements: situative background, discourse field, meaning dimension, and predicative mode (for a detailed explanation of the four elements see: Stolze, 2011). At this point, a legal translator analyzes a source text, taking into consideration the legal system and legal culture to which the text belongs, the domain within specific law disciplines (criminal law, civil law, family law, etc.), the terminology and its conceptualization, and finally, speech acts, passive form, cohesion markers, legal phraseology. In this way a legal translator deepens his pre-grounded understanding of the text and activates his knowledge base concerning the legal domain. All these four elements, as can be seen from the figure above, are interconnected:

Hermeneutical understanding, advancing top-down from the situational background over the discourse field and the meaning dimension until the concrete predicative mode, leads to an expansion of the text by added information, which is complementary to the bare linguistic information found on the text's surface structure. (Stolze, 2011:125)

In other words, translational reading leads to global and holistic understanding of the source text seen as a whole message. However, as has been mentioned, this is only the first stage of the translational process. In order 


\section{Beata Piecychna}

to translate, then, a translator has to use his findings obtained through the translational reading stage and represent them in the form of the target language. Below is a model of a hermeneutical translational writing stage:

Figure 2

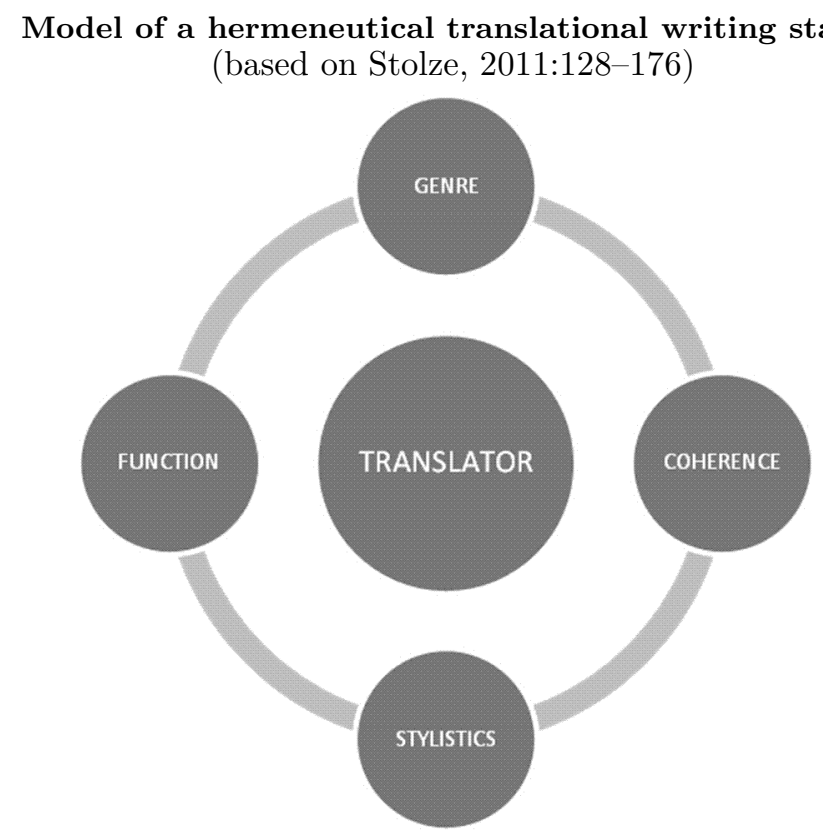

At this stage, a legal translator will usually focus on the analysis of the text type, the logic in the text structure, the functional style, and the communicative aim of the text. Similarly, as in the previous stage, all these four elements are interconnected and each of them leads to the formation of the target text. It should be noted that lack of consideration of any of these elements in the translational writing stage usually results in a disruption of the communicative goal of the text.

As in the two figures above, at the very centre of the whole translational process is the translator with his own competence. The success or failure of a legal translation activity depends on the translator's skills and knowledge concerning translation studies, linguistics, and law. Now let us look closely at our hermeneutical model of legal translation competence.

\section{The hermeneutical model of legal translation competence}

Below is a suggested model of the hermeneutical model of legal translation competence: 


\section{Figure 3}

A suggested hermeneutical model of legal translation competence

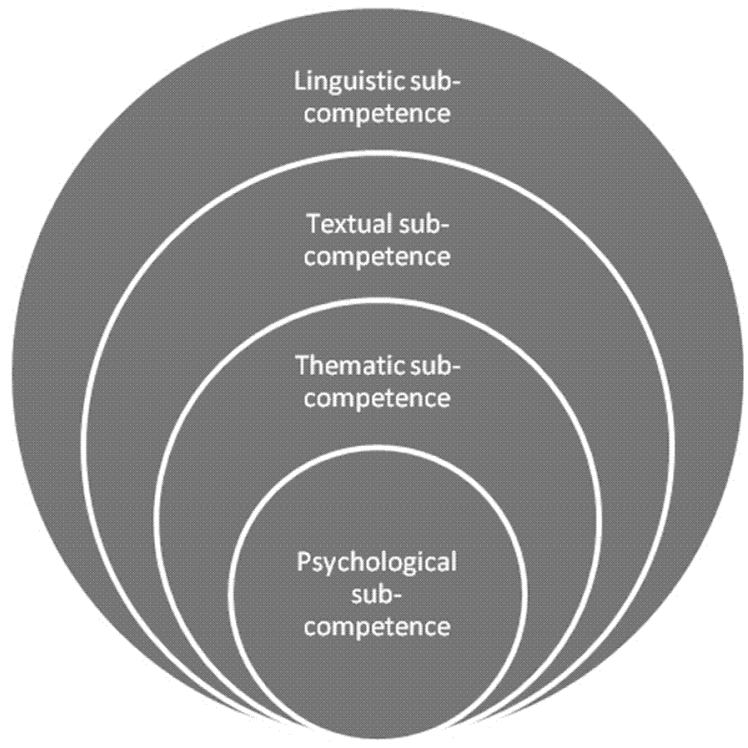

The proposed hermeneutical model is of both dynamic and circular character, which means that the specific sub-competences have so-called equal status and interrelate with each other. At the same time, each sub-competence is determined by the others, which simply indicates that they are complementary to each other. All these sub-competences form a global, hermeneutical, legal translation competence which is based on the translator as the central aspect of any translational process. Let us now look closely at each of the sub-competences.

- Psychological sub-competence: self-reflection upon one's own skills and knowledge; reflection upon one's own cultural and social position as a legal translator; acceptance of one's own limitations and possible lack of skills or knowledge; acceptance of the subjective nature of the translational process; self-criticism; self-motivation; willingness to develop one's own knowledge; willingness to pursue a career as a legal translator; attitude towards translation work; being a responsible, curious, patient, creative, hard-working, diligent, methodical, devoted, and imaginative person; the ability to identify and solve problems with appropriate strategies and techniques; the ability to analyze and interpret texts.

- Thematic sub-competence: understanding and knowledge of the differences between various legal systems and legal cultures; the ability to compare various foreign legal systems with reference to the specificity of the 


\section{Beata Piecychna}

translation task; understanding and knowledge of different sub-fields of law, such as civil law, criminal law, family law, international law, trade law, etc.; the ability to interpret and analyze a legal text.

- Textual sub-competence: knowledge of the typology of legal texts, legal genre conventions, legal terminology conceptualization, legal text register, legal text predicative mode and form; knowledge of formatting conventions; knowledge of legal text function in specialist communication; the ability to interpret and analyze a legal text.

- Linguistic sub-competence: knowledge of source and target languages in terms of grammar, lexis, stylistics, punctuation, spelling; knowledge of source and target legal language for specific purposes.

The four sub-competences reflect a holistic model of hermeneutical translation competence with reference to legal translation. The model's elements, namely psychological, thematic, textual, and linguistic subcompetences, are integrated, and their configuration makes the legal translation process different from other areas of specialized translation. A legal translator, be it a linguist with a specialization in legal translation or a foreign-language-proficient lawyer, must, first of all, understand a given text and be able to position it within the particular situational context with reference to the source and target legal systems. Hence, comparative law plays a crucial role in the effective realization of a translation task. As can be seen from the description of the four sub-competences of the hermeneutical model of legal translation competence, the knowledge of legal systems, understanding of differences between them, and the ability to interpret texts is a must for every legal translator. However, this is only possible, when the other necessary elements of the particular subcompetences are taken into consideration. Thus, it can be said in conclusion that the understanding of a given legal text can be achieved only if a translator possesses good psychological, thematic, textual, and linguistic sub-competences.

\section{Conclusion}

Despite an increasing awareness of, and interest in the construct of translation competence both in translation theory and translation didactics, it can be concluded that currently there is a lack of empirical research and theoretical work devoted specifically to particular types of translation: legal, medical, technical, audiovisual, literary, interpreting, etc. As far as legal translation competence is concerned, to the best of my knowledge, so far, 
there have only been two studies (mentioned above) devoted to models of legal translation competence. Therefore, more research is needed both in the subject of legal translation competence and legal translation as such. In the light of the relative lack of work concerning the subject of translation competence in the law field, an attempt has been made to fill the research gap and propose a hermeneutical model of legal translation competence, consisting of four sub-competences.

Bukowski's (2012) idea concerning contemporary translation competence models is particularly interesting. He proposes that the definitions and models of general translation competence, despite their endorsement by many authors, focus rather on the final translational product, neglecting the initial stage of every translational act, namely a translator's confrontation with a given source text. We can also refer here to the words of Kautz (2000:66) who writes that didactic practice shows that translation students are not aware of the importance of understanding in the translational process. In the light of the poor quality of many contemporary translations, it can be added that even professional translators are often unaware of how important understanding is in the translational process. Translational hermeneutists agree that proper understanding of a source message leads to the appropriate positioning of a text within the particular context, which often results in more effective translation work. But it is not only understanding that plays an important role in the translational process. The act of interpretation can also be distinguished as having a significant role. Having understood a text, a legal translator's task is to interpret the source message and transpose it into the target message. Thus, any translational act may be described as an activity bearing testimony to the hermeneutical commitment of a competent legal translator.

In spite of much criticism directed toward translation hermeneutics, it has to be realized that this sub-discipline of Translation Studies, as opposed to other translational approaches, emphasizes the paramount importance of the translator as being central to the whole act of creation of the target message and underlines the fact that this would be almost impossible without the initial stage in which the translator must confront a given text, a process requiring understanding and interpretation. Therefore, in this paper, a new holistic model has been proposed - a hermeneutical model of legal translation competence, in which apart from the usual components of sub-competences, such as the knowledge of the source and target languages, additional elements have been added, elements comprising a legal translator's hermeneutical competences, which, unfortunately, are neglected by many authors in their deliberations on translation and translation compe- 


\section{Beata Piecychna}

tence. It is hoped, therefore, that through this paper, more awareness of the great importance of understanding and interpretation as two complementary and necessary components in the process of legal translation will be raised.

\section{R E F E R E N C E S}

Alves, F. (1996). Veio-me um 'click' na cabeça: The Theoretical Foundations and the Design of a Psycholinguistically Oriented Empirical Investigation on German-Portuguese Translation Processes. Meta: Translator's Journal, 41 (1), 33-44. doi: 10.7202/001881ar.

Alves, F. \& Gonçalves, J.L. (2007). Modelling Translator's Competence: Relevance and Expertise under Scrutiny. In R. Stolze, M. Shlesinger \& Y. Gambier (Eds.), Doubts and Directions in Translation Studies: Selected Contributiond From the EST Congress, Lisbon 2004 (pp. 41-55). Amsterdam \& Philadephia: John Benjamins Publishing Company.

Bell, R.T. (1991). Translation and Translating. Theory and Practice. London \& New York: Longman.

Bhatia, V.K. (1993). Analysing Genre: Language Use in Professional Settings. London: Longman.

Bhatia, V.K. (2004). Worlds of Written Discourse: A Genre-Based View. London \& New York: Continuum.

Bukowski, P. (2012). Hermeneutyczne kompetencje tłumacza. In M. Piotrowska, A. Czesak, A. Gomola \& S. Tyupa (Eds.), Kompetencje ttumacza (pp. 125139). Kraków: Tertium.

Campbell, S.J. (1991). Towards a Model of Translation Competence. Meta: Translators' Journal, 36 (2-3), 329-343. doi: 10.7202/002190ar.

Cao, D. (2007). Translating Law. Clevedon, New York \& Ontario: Multilingual Matters.

Dancette, J. (1994). Comprehension in the Translation Process: An Analysis of Think-Aloud Protocols. In C. Dollerup \& A. Lindegaard (Eds.), Teaching Translation and Interpreting 2: Insights, Aims, Visions (pp. 113-120). Amsterdam \& Philadelphia: John Benjamins Publishing Company.

Dancette, J. (1995). Parcours de Traduction: Étude expérimentale du processus de comprehension. Lille: Presses Universitaires de Lille.

EMT extert group (2009). Competences for professional translators, experts in multilingual and multimedia communication. Retrieved October 1, 2013, from: http://ec.europa.eu/dgs/translation/programmes/emt/key_documents/emt_ competences_translators_en.pdf.

Fraser, J. (1993). Public Accounts: Using Verbal Protocols to Investigate Community Translator Training. Applied Linguistics, 14 (4), 325-343. 
Gadamer, H.G. (2004). Truth and Method. London \& New York: Continuum.

Göpferich, S. (2007). Research Project TransComp: The Development of Translation Competence. Retrieved October 1, 2013, from: http://gams.unigraz.at/fedora/get/container:tc/bdef:Container/get.

Göpferich, S. (2009). Towards a Model of Translation Competence and its Acquisition: the Longitudinal Study TransComp. In S. Göpferich, A.L. Jakobsen \& I.M. Mees (Eds.), Behind the Mind; Methods, Models and Results in Translation Process Research (pp. 11-37). Copenhagen: Samfundslitteratur Press.

Gouadec, D. (2007). Translation as a Profession. Amsterdam \& Philadelphia: John Benjamins Publishing Company.

Harris, B. (1977). The Importance of Natural Translation. Working Papers in Bilingualism, 12, 96-114.

Harris, B. \& Sherwood, B. (1978). Translating as an Innate Skill. In D. Gerver \& H. Wallace Sinaiko (Eds.), Language, Interpretation and Communication (pp. 155-170). New York \& London: Plenum.

Hejwowski, K. (2009). Kognitywno-komunikacyjna teoria przektadu. Warszawa: Wydawnictwo Naukowe PWN.

Hermans, T. (2009). Hermeneutics. In Routledge Encyclopedia of Translation Studies (pp. 130-132). Oxon \& New York: Routledge.

Hurtado Albir, A. (1996). La enseñanza de la traducción directa 'general.' Objetivos de aprendizaje y metodologia. In A. Hurtado Albir (Ed.), La enseñanza de la traducción (pp. 31-55). Castellón: Universitat Jaume I. Jääskeläinen, R. (1989). Translation Assignment in Professional Versus Non-professional Translation: a Think-Aloud Protocol Study. In C. Séguinot (Ed.), The Translation Process (pp. 87-98). Toronto: H.G. Publications.

Kautz, U. (2000). Handbuch Didaktik des Übersetzens und Dolmetschens. Munich: Goethe Institut.

Kelly, D. (2005). A Handbook for Translator Trainers. Manchester: St Jerome.

Kiraly, D. (1995). Pathways to Translation. Pedagogy and Process. Kent \& London: The Kent State University Press.

Koller, W. (1979). Einführung in die Übersetzungswissenschaft. Heidelberg: Quelle \& Meyer.

Krings. H.P. (1988). Was in den Köpfen von Übersetzern vorgeht. Tübingen: Gunter Narr.

Kussmaul, P. (1991). Creativity in the Translation Process: Empirical Approaches. In K.M. van Leuven \& T. Naaijkens (Eds.), Translation Studies: The State of the Art (pp. 91-101). Amsterdam: Rodopi.

Livbjerg, I. \& Mees I.M. (1999). A Study of the Use of Dictionaries in DanishEnglish Translation. In G. Hansen (Ed.), Probing the Process in Translation: Methods and Results. Copenhagen: Samfundslitteratur Press. 
Lorenzo, M.P. (1999). La seguridad del traductor professional en la traducción a una lengua extranjera. In G. Hansen (Ed.), Probing the Process in Translation: Methods and Results (pp. 121-134). Copenhagen: Samfundslitteratur Press.

Neubert, A. (2000). Competence in Language, in Languages, and in Translation. In B.J. Adab \& Ch. Schäffner (Eds.), Developing Translation Competence (pp. 3-18). Amsterdam \& Philadelphia: John Benjamins Publishing Company.

Obenaus, G. (1995). The Legal Translator as Information Broker. In M. Morris (Ed.), Translation and the Law (pp. 247-259). Amsterdam \& Philadelphia: John Benjamins Publishing Company.

Orozco, M., Hurtado Albir A. (2002). Measuring Translation Competence Acquisition. Meta: Translators' Journal, 47 (3), 375-402. doi: 10.7202/008022ar.

PACTE (2003). Building a Translation Competence Model. In F. Alves (Ed.), Triangulating Translation: Perspectives in Process Oriented Research (pp. 4366). Amsterdam \& Philadelphia: John Benjamins Publishing Company.

PACTE (2011). Results of the Validation of the PACTE Translation Competence Model: Translation Problems and Translation Competence. In A. Hild, E. Tiselius \& C. Alvstad (Eds.), Methods and Strategies of Process Research: Integrative Approaches in Translation Studies (pp. 317-343). Amsterdam \& Philadelphia: John Benjamins Publishing Company.

Palmer, R.E. (1969). Hermeneutics: Interpretation Theory in Schleiermacher, Dilthey, Heidegger. Evanston: Nortwestern University Press.

Piotrowska, M., Czesak, A., Gomola, A. \& Tyupa, S. (2012). Kompetencje ttumacza. Kraków: Tertium.

Presas, M. (2000). Bilingual Competence and Translation Competence. In B.J. Adab \& Ch. Schäffner (Eds.), Developing Translation Competence (pp. 1931). Amsterdam \& Philadelphia: John Benjamins Publishing Company.

Prieto Ramos, F. (2011). Developing Legal Translation Competence: An integrative Process-Oriented Approach. Comparative Legilinguistics - International Journal for Legal Communication, 5, 7-21.

Pym, A. (2003). Redefining Translation Competence in an Electronic Age. In Defence of a Minimalist Approach. Meta: Translators' Journal, 48 (4), 481-497. doi: 10.7202/008533ar.

Šarčevič, S. (1994). Translation and the Law: An Interdisciplinary Approach. In M. Snell-Hornby, F. Pöchhacker \& K. Kaindl (Eds.), Translation Studies. An Interdiscipline (pp. 301-307). Amsterdam \& Philadelphia: John Benjamins Publishing Company.

Šarčevič, S. (1997). New Approaches to Legal Translation. Hague, London \& Boston: Kluwer Law International.

Schäffner, C. (1993). Meaning and Knowledge in Translation. In Y. Gambier \& J. Tommola (Eds.), Translation and Knowledge (pp. 155-166). Turku: University of Turku. 
Shreve, G.M. (2006). The Deliberate Practice: Translation and Expertise. Journal of Translation Studies, 9 (1), 27-42.

Sofer, M. (2006). The Translator's Handbook. Rockville: Schreiber Publishing.

Stolze, R. (2011). The Translator's Approach - Introduction to Translational Hermeneutics: Theory and Examples from Practice. Berlin: Frank \& Timme.

Stolze, R. (2013). The Legal Translator's Approach to Texts. Humanities, 2, 56-71. doi: $10.3390 / \mathrm{h} 2010056$.

Tirkkonen-Condit, S. (1990). Professional vs. Non-Professional Translation: A Think-Aloud Protocol Study. In M.A.K. Halliday, J. Gibbons \& H. Nicholas (Eds.), Learning, Keeping and Using Language (pp. 381-394). Amsterdam \& Philadephia: John Benjamins Publishing Company.

Trosborg, A. (1997). Rhetorical Strategies in Legal Language: Discourse Analysis of Statutes and Contracts. Tübingen: Gunter Narr Verlag.

Whyatt, B. (2012). Translation as a Human Skill: From Predisposition to Expertise. Poznań: Wydawnictwo Naukowe.

Wills, W. (1976). Perspectives and Limitations of a Didactic Framework for the Teaching of Translation. In R.W. Brislin (Ed.), Translation. Applications and Research (pp. 117-137). New York: Gardner Press.

Wills, W. (1982). The Science of Translation. Problems and Methods. Tübingen: Gunter Narr.

Wills, W. (1996). Knowledge and Skills in Translator Behavior. Amsterdam \& Philadelphia: John Benjamins Publishing Company. 